\title{
NOTE
}

\section{Growth of Baltic Sea young-of-the-year herring Clupea harengus is resource limited}

\author{
Fredrik Arrhenius ${ }^{1, *}$, Sture Hansson \\ Department of Systems Ecology, Stockholm University, 10691 Stockholm, Sweden
}

\begin{abstract}
We have determined the in situ food consumption rate of young-of-the-year (YOY, length 25 to $94 \mathrm{~mm}$ ) Baltic Sea herring. This consumption increased with increasing food availability, which suggests that the growth rate of young Baltic herring is food limited. This has been described previously for larval stages, but not for metamorphosed fish. The daily food consumption rate of YOY herring decreased from about 8 to $15 \%$ of body weight for small fish in the summer to 0.6 to $2 \%$ for larger juveniles in late autumn.
\end{abstract}

KEY WORDS: Baltic Sea - Juveniles - Herring - Food consumption - Zooplankton

Herring Clupea harengus L. is a dominant predator on crustacean zooplankton in the Baltic Sea (e.g. Hansson et al. 1990, Rudstam et al. 1992, Arrhenius \& Hansson 1993). It is possible that the effects of this predation indirectly influence other trophic levels (cf. experiences from lakes; Carpenter et al. 1985, Carpenter \& Kitchell 1993). To evaluate the predation pressure exerted by herring on its prey (Hansson et al. 1990 , Rudstam et al. 1992, 1994), food consumption has been estimated from a bioenergetics model, based on physiological assumptions and field data on fish growth, habitat temperature, and diet. These analyses have shown that, of the total zooplankton consumption by the Baltic herring population, young-of-the-year (YOY) fish consume 38 to $76 \%$, making them the dominant zooplanktivorous age group (Arrhenius \& Hansson 1993, Arrhenius 1997). Although these results indicate intensive predation on zooplankton, there are few studies that present a quantitative relationship between food availability and zooplanktivory in the

\footnotetext{
- Present address. Institute of Marine Research, National Board of Fisheries, PO Box 4, 45321 Lysekil, Sweden. E-mail: f.arrhenius@imr.se
}

Baltic Sea (Rudstam et al. 1992, Thiel 1996). The objective of this study was to test if such a relationship exists.

Materials and methods. Using small charges of explosives (15 to $120 \mathrm{~g}$ of Primex $17 \mathrm{~mm}$, Nitro Nobel AB) herring were sampled at approximately $2 \mathrm{~h}$ intervals during ten $24 \mathrm{~h}$ periods between July and November 1992 and 1993 (data from 1992 are from Arrhenius \& Hansson 1994a,b). The explosives were detonated below the fish at varying depths (see Table 1) and explosion gases carried the fish to the surface where they were collected. The depth of the fish was found either empirically, from detonations on different depths, or from an echo sounder. Samples of about 10 fish per length class were taken within $10 \mathrm{~min}$ after a detonation. In 1992, the fish were immediately preserved in $70 \%$ ethanol; in 1993 they were deep-frozen $\left(-18^{\circ} \mathrm{C}\right)$. All sampling was done in coastal areas of the northern Baltic proper (around $58^{\circ} \mathrm{N}, 17^{\circ} \mathrm{E}$ ).

In the laboratory, the total length of each fish was measured to the nearest $\mathrm{mm}$ and the wet weight (WWT) was determined to the nearest $\mathrm{mg}$. Weight data were corrected for effects of preservation (WWT = $0.02+(1.05 \times$ ethanol-weight $[\mathrm{g}]), \mathrm{r}^{2}=0.99, \mathrm{n}=40$ and $W W T=0.08+(1.02 \times$ deep-frozen-weight $[\mathrm{g}]), \mathrm{r}^{2}=0.99$, $\mathrm{n}=200$ ). Fish dry weight (DWT) was estimated as DWT $=-0.022+(0.22$ WWT [g] $), \mathrm{r}^{2}=0.99, \mathrm{n}=300$. Stomachs were removed and stored in $70 \%$ ethanol for at least 1 mo to stabilise the biomass (Karjalainen 1992). Each stomach was cut open, rinsed with ethanol and food particles collected on a glass fibre filter (Whatman GF/F in 1992 and GF/D in 1993). DWT of stomach content was determined to the nearest $\mu \mathrm{g}$ (Sartorius micro M3P) after drying to stable weight at $60^{\circ} \mathrm{C}$.

We assumed that the zooplankton prey used by the fish were found in the depth interval between the sur- 
face and the depth where the fish were caught. This water layer was sampled using a $90 \mu \mathrm{m}$ WP-2 zooplankton net, which was towed vertically at a speed of $0.5 \mathrm{~m} \mathrm{~s}^{-1}$. One daytime sample was taken on each sampling date, and immediately after collection it was preserved in a $4 \%$ buffered formaldehyde solution. Time constraints prevented us from taking more than
1 zooplankton sample per sampling date, but an earlier study in this area has shown that the horizontal distribution of zooplankton is relatively even (coefficient of variation among replicates $-30 \%$; Johansson et al. 1993). Before counting under an inverted microscope, the zooplankton samples were subsampled (Kott 1953) and at least 500 specimens from each sam-

Table 1. Fish length (in $5 \mathrm{~mm}$ intervals), dry weight, evacuation rates and daily food ration of young-of-the-year (YOY) herring in 1992 and 1993. The temperature intervals given are for 0 to $10 \mathrm{~m}$ in July/August and 0 to $30 \mathrm{~m}$ in September/October, corresponding to depth occupied by the YOY at these sampling occasions. The assumed feeding period was between sunrise and sunset. The number of fish analysed is not equal to the number of fish killed at different sampling dates and depths

\begin{tabular}{|c|c|c|c|c|c|c|c|c|c|}
\hline \multirow[t]{2}{*}{ Date } & \multirow[t]{2}{*}{$\begin{array}{l}\text { Depth } \\
(\mathrm{m})\end{array}$} & \multirow{2}{*}{$\begin{array}{l}\text { Fish } \\
\text { length } \\
\text { interval } \\
(\mathrm{mm})\end{array}$} & \multirow[t]{2}{*}{$\mathrm{n}$} & \multicolumn{2}{|c|}{$\begin{array}{c}\text { Fish } \\
\text { dry weight } \\
(\mathrm{g})\end{array}$} & \multirow[t]{2}{*}{$\begin{array}{c}\text { Evacuation } \\
\text { rate, ER } \\
\left(\mathrm{h}^{-1}\right)\end{array}$} & \multirow{2}{*}{$\begin{array}{c}\text { Daily food } \\
\text { ration } \\
\text { (\% of body } \\
\text { weight, DWT) }\end{array}$} & \multirow[t]{2}{*}{$\begin{array}{l}\text { Temp. } \\
{\left[{ }^{\circ} \mathrm{C}\right)} \\
\text { Mean }\end{array}$} & \multirow[t]{2}{*}{$\begin{array}{c}\text { Feeding } \\
\text { period } \\
\text { (h) }\end{array}$} \\
\hline & & & & Mean & $\mathrm{SD}$ & & & & \\
\hline 1992 & & $25-29$ & 95 & 0.0060 & 0.0020 & 0.35 & 11 & 17.4 & \multirow{6}{*}{18.0} \\
\hline \multirow[t]{5}{*}{ Jul $16-17$} & 3 & $30-34$ & 110 & 0.013 & 0.00 .38 & 0.39 & 15 & 17.4 & \\
\hline & & $35-39$ & 83 & 0.031 & 0.0060 & 0.38 & 15 & 17.4 & \\
\hline & 10 & $30-34$ & 138 & 0.013 & 0.0035 & 0.29 & 12 & 1.7 .4 & \\
\hline & & $35-39$ & 129 & 0.028 & 0.0051 & 0.38 & 9.9 & 17.4 & \\
\hline & & $40-44$ & 112 & 0.052 & 0.010 & 0.32 & 11 & 17.4 & \\
\hline \multirow[t]{5}{*}{ Aug 5-6 } & & $30-34$ & 60 & 0.017 & 0.0046 & 0.24 & 7.1 & 16.5 & \multirow{5}{*}{17.0} \\
\hline & 10 & $35-39$ & 89 & 0.034 & 0.0058 & 0.26 & 11 & 16.5 & \\
\hline & & $40-44$ & 104 & 0.061 & 0.011 & 0.23 & 8.5 & 16.5 & \\
\hline & & $45-49$ & 110 & 0.095 & 0.015 & 0.21 & 7.1 & 16.5 & \\
\hline & & $50-54$ & 87 & 0.14 & 0.016 & 0.27 & 9.6 & 16.5 & \\
\hline \multirow[t]{4}{*}{ Aug $26-27$} & & $45-49$ & 82 & 0.099 & 0.015 & 0.29 & 12 & 15.0 & \multirow{4}{*}{15.5} \\
\hline & 15 & $50-54$ & 125 & 0.14 & 0.015 & 0.33 & 9.5 & 15.0 & \\
\hline & & $55-59$ & 130 & 0.20 & 0.023 & 0.21 & 8.3 & 15.0 & \\
\hline & & $60-64$ & 108 & 0.27 & 0.028 & 0.26 & 7.9 & 15.0 & \\
\hline \multirow[t]{3}{*}{ Sep $17-18$} & & $60-64$ & 54 & 0.25 & 0.024 & 0.20 & 4.8 & 13.2 & \multirow{3}{*}{12.5} \\
\hline & 20 & $65-69$ & 62 & 0.30 & 0.026 & 0.19 & 3.5 & 13.2 & \\
\hline & & $70-74$ & 55 & 0.38 & 0.036 & 0.28 & 4.8 & 13.2 & \\
\hline \multirow[t]{3}{*}{ Oct $27-28$} & & $70-74$ & 39 & 0.37 & 0.080 & 0.16 & 1.4 & 8.7 & \multirow{3}{*}{9.0} \\
\hline & 35 & $75-79$ & 50 & 0.51 & 0.090 & 0.20 & 2.2 & 8.7 & \\
\hline & & $80-84$ & 63 & 0.64 & 0.11 & 0.23 & 1.8 & 8.7 & \\
\hline 1993 & & $25-29$ & 174 & 0.0070 & 0.15 & 0.34 & 8.2 & 15.9 & \multirow{5}{*}{18.0} \\
\hline \multirow[t]{4}{*}{ Jul $15-16$} & 10 & $30-34$ & 187 & 0.018 & 0.012 & 0.37 & 7.7 & 15.9 & \\
\hline & & $35-39$ & 168 & 0.030 & 0.0071 & 0.39 & 8.5 & 15.9 & \\
\hline & & $40-44$ & 162 & 0.059 & 0.010 & 0.37 & 6.1 & 159 & \\
\hline & & $45-49$ & 97 & 0.091 & 0.014 & 0.34 & 9.8 & 15.9 & \\
\hline Aug 2-3 & & $30-34$ & 101 & 0.015 & 0.013 & 0.28 & 7.4 & 15.4 & \\
\hline & 10 & $35-39$ & 117 & 0.035 & 0.0079 & 0.39 & 8.3 & 15.4 & \\
\hline & & $40-44$ & 96 & 0.049 & 0.011 & 0.33 & 9.5 & 15.4 & 17.0 \\
\hline & & $45-49$ & 68 & 0.098 & 0.015 & 0.36 & 9.1 & 15.4 & \\
\hline & & $50-54$ & 87 & 0.092 & 0.019 & 0.33 & 9.6 & 154 & \\
\hline Aug $24-25$ & & $55-59$ & 101 & 0.23 & 0.029 & 0.22 & 7.2 & 13.9 & \\
\hline & 10 & $60-64$ & 130 & 0.29 & 0.036 & 0.24 & 7.0 & 13.9 & 15.5 \\
\hline & & $65-69$ & 111 & 0.36 & 0.040 & 0.25 & 7.5 & 13.9 & \\
\hline Oct $6-7$ & & $60-64$ & 27 & 0.20 & 0.033 & 0.26 & 7.8 & 9.7 & \\
\hline & 10 & $65-69$ & 43 & 0.37 & 0.042 & 0.32 & 6.1 & 9.7 & \\
\hline & & $70-74$ & 62 & 0.45 & 0.067 & 0.27 & 5.1 & 9.7 & 11.5 \\
\hline & & $75-79$ & 75 & 0.47 & 0.087 & 0.27 & 5.4 & 9.7 & \\
\hline & & $80-84$ & 54 & 0.49 & 0.078 & 0.21 & 3.0 & 9.7 & \\
\hline Nov $2-3$ & & $75-79$ & 93 & 0.56 & 0.097 & 0.23 & 13 & 5.8 & \\
\hline & 30 & $80-84$ & 127 & 0.73 & 0.11 & 0.25 & 1.1 & 5.8 & 9.0 \\
\hline & & $85-89$ & 118 & 0.79 & 0.1 .2 & 0.21 & 0.92 & 5.8 & \\
\hline & & $90-94$ & 45 & 0.74 & 0.19 & 0.22 & 0.58 & 5.8 & \\
\hline Total no. of fish: & & & 4128 & & & & & & \\
\hline
\end{tabular}


ple were identified to the lowest possible taxonomic level. Biomass was estimated from species and stagespecific values on individual WWT (Hernroth 1985, further details in Hansson et al. 1990), of which $13 \%$ was assumed to be DWT (Mullin 1969). YOY herring consume zooplankton roughly in proportion to their relative abundances (Arrhenius 1996) and we assumed that the food available to YOY herring was in direct proportion to the biomass in the zooplankton samples.

The stomach content of YOY herring showed a clear diel variation, indicating that they are eating only during daylight hours (sunrise to sunset; Arrhenius \& Hansson 1994a). From these data, consumption rate (Cons, $\mathrm{g} \mathrm{g}^{-1}$ time interval ${ }^{-1}$ ) was estimated by the method of Elliott \& Persson (1978):

$$
\text { Cons }=\frac{\left(S_{t}-S_{0} e^{-E R \times t}\right) E R \times t}{1-e^{E R \times t}}
$$

where $S_{0}$ and $S_{1}$ are specific stomach contents (expressed as the stomach content divided by the body mass, both in g DWT) at the beginning and end of a $t$ (hours long) period (generally $\sim 2 \mathrm{~h}$ ). $E R$ is the gastric evacuation rate, estimated from the decline in stomach content during the non-feeding period (assuming an exponential evacuation rate; Elliott \& Persson 1978). We calculated the $E R$ between approximately $1 \mathrm{~h}$ after sunset and $1 \mathrm{~h}$ before sunrise. Calculations were done separately for each sampling date and for $5 \mathrm{~mm}$ wide size classes of fish. More details are found in Arrhenius \& Hansson (1994a,b).

Growth of a fish may be limited not only by food, but also by temperature if food is unlimited (cf. Kitchell et al. 1977). However, for Baltic Sea zooplanktivores, such as herring, temperature and food availability are correlated. Generally, the zooplankton population peaks in the summer when the water temperature is high and population is minimal in winter when the temperature also reaches its lowest values (Johansson 1992). To evaluate which of these factors was most limiting, zooplankton abundance or temperature, both were correlated with the hourly food consumption during the feeding (= daylight) period. However, since the weight-specific consumption rate (WSC) varied with size, we also included fish size in the analysis. This was done by using dummy variables as described by Chatterjee \& Price (1991, p. 95 to 106). The regression equation fitted to the data became:

$$
W S C=k_{0}+k_{1} \times z o o p l+k_{2} \times t e m p+\sum_{i=3}^{16} k_{1} \times d u m m y_{i}
$$

where zoopl, temp and dummy $y_{3}$-dummy $y_{16}$ refer to the zooplankton biomass, temperature and the dummy variables for the 14 size classes of fish.

Results and discussion. Zooplankton samples were dominated by copepods (Fig. 1), mainly Eurytemora affinis hirundoides, Temora longicornis and Acartia spp. The cladocerans Bosmina longispina maritima, Pleopsis polyphemoides and rotifers each constituted only 1 to $15 \%$ of the biomass. The proportions of different zooplankton taxa were almost the same both years and the seasonal pattern followed earlier observations from the same area (Johansson 1992).

A total of 4128 YOY herring, ranging from 25 to 94 $\mathrm{mm}$ in length and 0.006 to $0.79 \mathrm{~g}$ DWT, were analysed. The estimated daily food consumption of YOY herring was 8 to $15 \%$ of the body weight for small fish in the
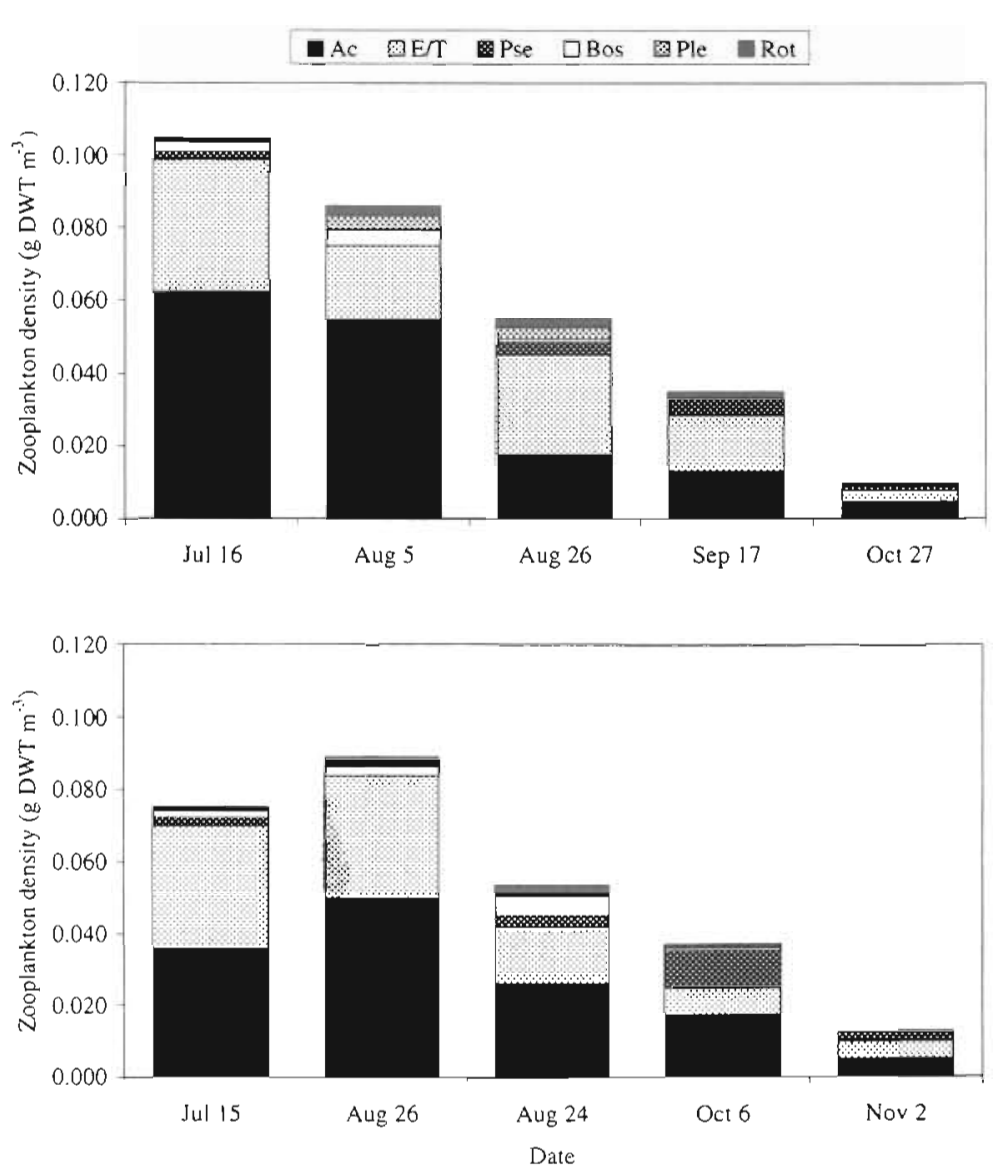

Fig. 1. Biomasses of rotifers, cladocerans and copepods for 1992 and 1993. Dominating species within each group are shown separately. Ac: Acartia spp., E/T: Eurytemora affinis hirundoides/Temora longicornis, Pse: Pseudocalanus minutus elongatus, Bos: Bosmina longispina maritima, Ple: Pleopsis polyphemoides, Rot: Rotatoria. E. affinis hirundoides and T. longicornis are merged in this graph, as they are difficult to separate in stomach contents from fish 


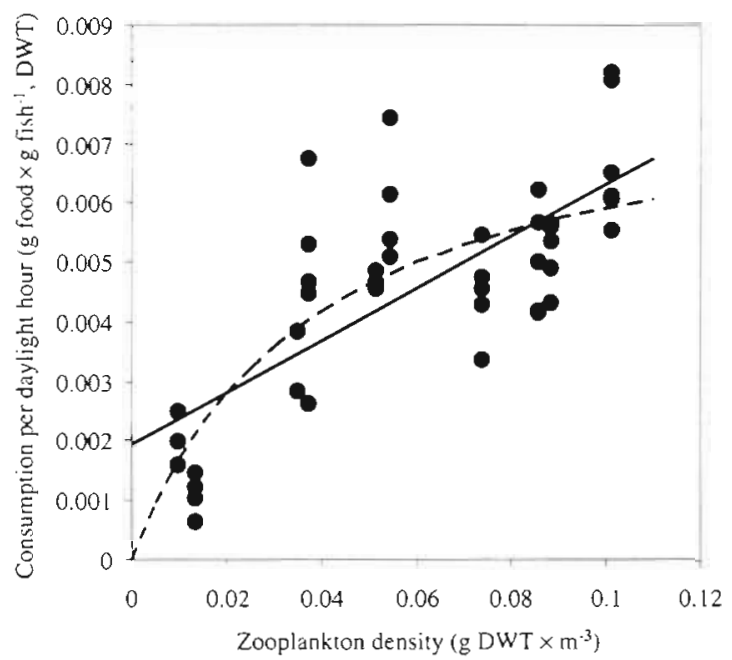

Fig. 2. Specific food consumption per hour (g DWT) of YOY Baltic herring plotted against the zooplankton density (O). The lines fitted to the data show a linear fit $(-)$ (WSC $=1.9 \times$ $\left.10^{-3}+4.4 \times 10^{-2} \times z o o p l\right)$ and a functional response Type II curve $(---)\left(\right.$ WSC $\left.=\frac{0.21 \times \mathrm{zoopl}}{1+26 \times \mathrm{zoopl}}\right)$

summer and 0.6 to $2 \%$ for larger juveniles in late autumn (Table 1). These consumption rates are similar to those observed in other field studies on YOY herring (Checkley 1984, Franek 1988) and are also consistent with the bioenergetics and growth rate of young herring (Arrhenius 1998).

In the regression analyses with food consumption as a function of temperature, zooplankton abundances and fish size (Eq. 2), the only statistically significant coefficient was that for the zooplankton biomass $\left(k_{1}=4.5 \times 10^{-2}, t=2.11, \mathrm{p}<0.05\right)$. Corresponding values for temperature were $k_{2}=-4.1 \times 10^{-5}$, $t=-0.222$ and $\mathrm{p}>0.8$. When using only the zooplanktor biomass as the independent variable, the regression became highly significant $\left(k_{1}=4.4 \times 10^{-2}\right.$, $t=7.07, p<0.001, r^{2}=0.55$ ). If a functional response Type II curve (Holling 1959) was fitted to the data, a slight increase in the correlation coefficient was obtained $\left(r^{2}=0.63\right.$, Fig. 2)

An implication of our results is that the food availability influences the growth of young Baltic herring (food consumption rate increases with increasing prey densityl. This has been described before for larval stages (i.e. Kiørboe et al. 1988, Fortier \& Gagné 1990, the list is not supposed to be complete) but not for metamorphosed fish. This may influence recruitment either directly through starvation mortality or indirectly by influencing growth rate and hence the vulnerability to predation (Houde \& Schekter 1981). To support this theory, Parmanne \& Sjoblom (1988) have shown a positive correlation between Baltic herring recruitment and zooplankton abundance.
Our result, that at least YOY herring are resource limited, is of relevance not only from a basic science perspective. It has often been suggested that eutrophication of the Baltic has favoured herring (e.g. reviews by Hansson 1985, Hansson \& Rudstam 1990, Thurow 1997). Prerequisites for this are that the production of crustacean zooplankton has increased in response to an increased primary production, and that herring are food limited and can respond to this increased production. Our results presented here, and recently published articles that describe growth and condition (fatness) changes in herring due to changes in the food supply (Raid \& Lankov 1995, Flinkman et al. 1998), indicate that herring is food limited and likely to respond to changes at lower trophic levels.

Acknowledgements. We are grateful for valuable criticisms from Massimiliano Cardinale, Stellan Hamrin, Ragnar Elmgren and 3 anonymous reviewers. Björn Klinga helped in the field and the laboratory. Financial support for collecting and analysing fish and zooplankton was provided by the Swedish Natural Science Research Council, The Royal Swedish Academy of Sciences (Hierta-Retzius foundation) Lars Hiertas foundation and Stockholm Centre for Marine Research. The final analysis of data and compilation of the manuscript was made possible through a European Commission grant (contract Mas3-CT96-0058)

\section{LITERATURE CITED}

Arrhenius F (1996) Diet composition and food selectivity of 0-group herring (Clupea harengus L.) and sprat (Sprattus sprattus (L.)) in the northern Baltic Sea. ICES J Mar Sci 53:701-712

Arrhenius F (1997) Top-down controls by young-of-the-year herring (Clupea harengus) in the northern Baltic proper. In: Forage fishes in marine ecosystems. Proc Int Symp Role Forage Fish Mar Ecosyst, Alaska Sea Grant College Program Report No. 97-01. University of Alaska, Fairbanks, p 77-86

Arrhenius $F$ (1998) Variable length of daily feeding period in bioenergetics modelling: a test with 0 -group Baltic herring. J Fish Biol 52:855-860

Arrhenius F, Hansson S (1993) Food consumption of larval young and adult herring and sprat in the Baltic Sea. Mar Ecol Prog Ser 96:125-137

Arrhenius F, Hansson S (1994a) In situ consumption by young-of-the-year Baltic Sea herring Clupea harengus: a test of predictions from a bioenergetics model. Mar Ecol Prog Ser 110:145-149

Arrhenius F, Hansson S (1994b) Erratum re: Arrhenius $F$, Hansson S (1994) Mar Ecol Prog Ser 110:145-149. Mar Ecol Prog Ser 114:314

Carpenter SR, Kitchell JF (1993) The trophic cascade in lakes Cambridge University Press, Cambridge

Carpenter SR, Kitchell JF, Hodgson JR (1985) Cascading trophic interactions and lake productivity. Bioscience 35 : $634-639$

Chatterjee S, Price B (1991) Regression analysis by example. John Wiley \& Sons, Inc, New York

Checkley DM Jr (1984) Relation of growth to ingestion for lar- 
vae of Atlantic herring Clupea harengus and other fish. Mar Ecol Prog Ser 18:215-224

Elliott JM, Persson L (1978) The estimation of daily rates of food consumption for fish. J Anim Ecol 47:977-991

Flinkman J, Aro E, Vuorinen I, Viitasalo M (1998) Changes in northern Baltic zooplankton and herring nutrition from 1980 s to 1990s: top-down and bottom-up processes at work. Mar Ecol Prog Ser 165:127-136

Fortier L, Gagné JA (1990) Larval herring (Clupea harengus) dispersion, growth, and survival in the St. Lawrence estuary: match/mismatch or membership/vagrancy? Can J Fish Aquat Sci 47:1898-1912

Franek D (1988) 0+ smelt (Osmerus eperlanus L.) and herring (Clupea harengus L.) in the food chain of the Barter Bodden. Comm Meet Int Coun Explor Sea CM ICES 1988/J:13

Hansson S (1985) Effects of eutrophication on fish communities, with special reference to the Baltic Sea-a literature review. Report, Institute of Freshwater Research, Drottningholm 62:36-56

Hansson S, Rudstam L (1990) Eutrophication and Baltic fish communities. Ambio 19:123-125

Hansson S, Larsson U, Johansson S (1990) Selective predation by herring and mysids, and zooplankton community structure in a Baltic Sea coastal area. J Plankton Res 12: 1099-1116

Hernroth L (1985) Recommendations on methods for marine biological studies in the Baltic Sea. Mesozooplankton biomass assessment. Baltic Marine Biologists, Publ. no. 10, Lysekil

Holling CS (1959) The components of predation as revealed by a study of small-mammal predation of the european pine sawfly. Can Entomol 91:293-320

Houde ED, Schekter RC (1981) Growth rates, rations and cohort consumption of marine fish larvae in relation to prey concentrations. Rapp P-V Reun Cons Int Explor Mer 178:441-453

Johansson S (1992) Regulating factors for coastal zooplankton community structure in the northern Baltic proper. PhD thesis, Stockholm University, Stockholm

Editorial responsibility: Otto Kinne (Editor) Oldendorf/Luhe, Germany
Johansson S, Hansson S, Araya-Nunez O (1993) Temporal and spatial variation of coastal zooplankton in the Baltic Sea. Ecography 16:167-173

Karjalainen J (1992) Effects of different preservation methods on total length and weight of larval vendace (Coregonus albula (L.)). Nordic J Freshw Res 67:88-90

Kiørboe T, Munk P, Richardson $\mathrm{K}$, Christensen V, Paulsen $\mathrm{H}$ (1988) Plankton dynamics and larval herring growth, drift and survival in a frontal area. Mar Ecol Prog Ser 44: 205-219

Kitchell JF, Stewart DJ, Weininger D (1977) Application of a bioenergetics model to yellow perch (Perca flavescens) and walleye (Stizostedion vitreum vitreum). J Fish Res Board Can 34:1922-1935

Kott P (1953) Modified whirling apparatures for the subsampling of plankton. Aust J Mar Freshw Res 4:387-393

Mullin MM (1969) Production of zooplankton in the ocean: the present status and problems. Oceanogr Mar Biol Annu Rev 7:293-314

Parmanne R, Sjöblom V (1988) The abundance of spring spawning Baltic herring larvae in the seas around Finland in 1982 and 1983, zooplankton abundance and the herring year class strength. Finn Fish Res 7:1-11

Raid T, Lankov A (1995) Recent changes in the growth and feeding of Baltic herring and sprat in the northeastern Baltic Sea. Proc Estonian Acad Sci Ecol 5:38-55

Rudstam LG, Hansson S, Johansson S, Larsson U (1992) Dynamics of planktivory in a coastal area of the northern Baltic Sea. Mar Ecol Prog Ser 80:159-173

Rudstam LG, Aneer G, Hildén M (1994) Top-down control in the pelagic Baltic ecosystem. Dana 10:105-129

Thiel R (1996) The impact of fish predation on the zooplankton community in a southern Baltic Bay. Limnologica 26: $123-137$

Thurow $F$ (1997) Estimation of the total fish biomass in the Baltic Sea during the 20th century. Ices J Mar Sci 54: $444-461$

Submitted: March 11, 1999; Accepted: October 26, 1999

Proofs received from author(s): December 7, 1999 